\title{
Psychiatric illness and behavioural problems in adults with learning disability and epilepsy
}

\author{
Shoumitro Deb* \\ Division of Psychological Medicine, University of \\ Wales College of Medicine, Health Park, Cardiff, \\ CF4 $4 X N$, UK
}

\author{
Joseph Joyce \\ Northgate Hospital, Morpeth, Northumberland, \\ NE61 3BP, UK
}

\begin{abstract}
We retrospectively collected data on the rate and type of psychiatric illness and behavioural problems on 143 adults with learning disability and epilepsy. $55 \%$ of the cohort showed behavioural problems. $19 \%$ showed physical aggression, $17 \%$ showed verbal aggression and temper tantrums, and $13 \%$ showed self injurious behaviour. The overall rates of behavioural problems and different types of behaviours found in the current study cohort are similar to what was found before in learning disabled adults in general, as well as in epileptic and non-epileptic learning disabled adults. Psychiatric diagnosis was made in $12.6 \%$ of the cohort. A combined diagnosis of schizophrenia, delusional disorder and schizo-affective disorder was most common $(5 \%)$, followed by a diagnosis of depressive episode (3\%), but no one had a diagnosis of bipolar affective disorder.
\end{abstract}

Keywords: Learning disability, epilepsy, psychiatric illness, behavioural disorders

\section{Introduction}

Prevalence of epilepsy is higher in adults with learning disability than the general population [7]. It is also known that a high proportion of learning disabled adults manifest behavioural problems [17]. However, the rate of behavioural problems is not significantly higher in learning disabled adults with epilepsy compared with those learning disabled adults who do not have a history of epilepsy [4]. Despite the difficulty of diagnosing psychiatric illness in adults with learning disability, prevalence of psychiatric illness may be

${ }^{*}$ Corresponding author: S. Deb, Division of Psychological Medicine, University of Wales College of Medicine, Health Park, Cardiff, CF4 4XN, UK. Tel.: +44 1222 562323; Fax: +44 1222 555047; E-mail: Deb@Cardiff.ac.uk. higher in this population as compared with the general population of average intelligence [9].

The complex relationship between psychiatric disorders, epilepsy and learning disability needs further investigation. It is also important to assess the relative impact of epilepsy-related factors such as seizure type, duration of seizure, EEG findings on behaviour and psychiatric illness among learning disabled adults with epilepsy. We therefore studied the extent and type of psychiatric illness and behavioural problems in a population-based sample of adults with learning disability and epilepsy. We also analysed the relative impact of epilepsy-related factors on patients' mental state.

\section{Method}

All 143 learning disabled adult residents of a health district in South Wales in the UK who were known to have epilepsy were included in this study. Names of these subjects were collected from the following sources (a) agencies providing services for learning disabled adults within the community, (b) local specialist hospital clinics for the treatment of epilepsy and (c) adult learning disabled residents of the health district who lived in a local hospital, which was due to close within the next two years.

A purpose-designed questionnaire was devised to gather information on the following areas: subject's age, sex, severity of learning disability (mild $I Q=70$ 50 , moderate $I Q=49-35$, severe $I Q<35$ ), list of antiepileptic and neuroleptic medication received by the subjects, duration of epilepsy, occurrence of epileptic seizure during the one year period prior to the study (active epilepsy), type of epileptic seizure and their frequency, type of EEG abnormality if any, presence of associated behavioural problems and psychiatric illness. Medical case-notes of these 143 subjects were scrutinised in detail for the purpose of gathering above information and many of these subjects and their carers were interviewed by the authors.

Diagnosis of epileptic seizure types was made according to the guidelines in the International Classifi- 
cation of Epileptic Seizures [3]. Seizure type was diagnosed on the basis of clinical history depending on the carer's description of behaviour during a seizure. As an EEG could not be performed on a number of study subjects, seizure type was diagnosed only on the basis of clinical features. Information regarding severity of learning disability, and types of behavioural problems and psychiatric illness was gathered from the medical case-notes, and where possible were verified by observer information and direct examination of the subjects. A retrospective diagnosis of psychiatric illnesses was made based on the International Classification of Diseases - 10th revision (ICD-10) [18]. Results of the EEG recorded in the medical case notes were obtained. Spikes, polyspikes, spike wave, sharp wave, sharp and slow waves were accepted as epileptiform activities in the EEG.

\section{Results}

\subsection{Demographic data}

Age range of 143 subjects was between 20 and 83 years $(40.66 \pm 13.26) .131(91.6 \%)$ were between age 20 and 64, and $12(8.4 \%)$ were aged over 64 years. There were 82 males $(57.3 \%)$ and $61(42.7 \%)$ females in the overall cohort. $6(4.2 \%)$ had a borderline intelligence, $18(12.6 \%)$ had mild, 23 (16.1\%) had moderate, and $80(55.9 \%)$ had severe learning disability. In $79(55 \%)$ cases no EEG result was available. Among 64 subjects for whom EEG results were available, 46 (72\%) showed abnormality. Further details on characteristics of epileptic seizures on this cohort are described in a separate paper [6].

\subsection{Behavioural problems}

Seventy nine subjects (55\%) showed behavioural problems. Common types of behavioural problem included physical aggression in 27 (19\%) cases, shouting/screaming and verbal aggression including temper tantrums in 25 (17\%) cases, self injurious behaviour in the form of biting, hair pulling, head banging, and putting fingers into the throat in 19 (13\%) cases. Less commonly manifested behavioural problems included pica in $5(3 \%)$ cases, wandering and absconding behaviour in $4(3 \%)$ cases, sleep problems in $4(3 \%)$ cases, over-activity/excessive agitation in 3 (2\%) cases, sexual delinquency in $2(1 \%)$ cases. One $(0.7 \%)$ subject had a history of repeated arson, 1 had a history of drug abuse and another had a history of public order offence. Two subjects showed cyclical changes in their mood and behaviour. One person had autistic features and 3 subjects showed behaviours related to non-epileptic pseudoseizure.

Proportion of subjects with behavioural problems in different subgroups of the cohort is shown in Table 1 . However, $63 \%(n=72)$ of those who sustained generalised tonic clonic seizures (GTCS) compared with $31 \%(n=5)$ of those who did not sustain GTCS showed behavioural problems. This difference was statistically significant $\left(\chi^{2}=5.9, \mathrm{df}=1\right.$, $p=0.01$ ). Apart from GTCS, no other seizure-type had shown any statistically significant relation with the rate of behavioural problems. Neither was there any relation between the rate of behavioural problems and (a) seizure-frequency ( $<1 /$ month vs $>1 /$ month), or (b) types of antiepileptic medication received by the subjects (i.e., carbamazepine, sodium valproate and lamotrigine).

\subsection{Psychiatric illness}

Eighteen (12.6\%) subjects had a psychiatric diagnosis. Types of psychiatric illness diagnosed were as follows; schizophrenia in $2(1.4 \%)$ cases, unspecified non-organic psychosis in $3(2 \%)$ cases, schizoaffective disorder in $1(0.7 \%)$ case, delusional disorder in 4 (3\%) cases, depressive episode in $4(3 \%)$ cases, generalised anxiety disorder in $1(0.7 \%)$ case, and dementia in $3(2 \%)$ cases. No one had a diagnosis of bipolar affective disorder. There was evidence of cyclical changes in mood and behaviour in 2 cases. The proportion of subjects with a psychiatric illness in different subgroups of the cohort are shown in Table 2. The proportion of subjects with and without a psychiatric illness, and with and without behavioural problems in different subgroups according to EEG findings are shown in Table 3. Rate of psychiatric illness was significantly higher among those whose EEG showed epileptiform changes compared with those who did not show epileptiform changes in their EEG (see Table 3).

$13 \%(n=15)$ of those who sustained GTCS, $24 \%$ $(n=6)$ of those who sustained complex partial seizure and $5 \%(n=1)$ of those who sustained absence seizure had a psychiatric illness. Inter-group comparison of the rate of psychiatric illness revealed no statistically significant difference either according to the seizure type or the seizure-frequency. Similarly, a comparison of the rate of psychiatric illness in different groups according to types of antiepileptic drugs received did not reveal any statistically significant difference. 
Table 1

Percentage of subjects with or without behavioural problems in different subgroups of the cohort

\begin{tabular}{|c|c|c|c|c|c|c|c|c|}
\hline & \multicolumn{2}{|c|}{ Gender } & \multicolumn{2}{|c|}{ Age } & \multicolumn{2}{|c|}{$\begin{array}{l}\text { Degree of learning } \\
\text { disability }\end{array}$} & \multicolumn{2}{|c|}{ Accommodation } \\
\hline & $\begin{array}{c}\text { Male } \\
(n=82)\end{array}$ & $\begin{array}{l}\text { Female } \\
(n=61)\end{array}$ & $\begin{array}{l}18-64 \text { yrs } \\
(n=131)\end{array}$ & $\begin{array}{l}>64 \text { yrs } \\
(n=12)\end{array}$ & $\begin{array}{c}\text { Mild } \\
(n=24)\end{array}$ & $\begin{array}{l}\text { Severe / Moderate } \\
\quad(n=103)\end{array}$ & $\begin{array}{l}\text { Hospital } \\
(n=78)\end{array}$ & $\begin{array}{l}\text { Community } \\
(n=65)\end{array}$ \\
\hline $\begin{array}{l}\text { Subjects with } \\
\text { behavioural } \\
\text { problems }\end{array}$ & 64 & 54.5 & 61 & 40 & 69.5 & 58 & 61 & 58 \\
\hline \multirow{3}{*}{$\begin{array}{l}\text { Subjects } \\
\text { without } \\
\text { a behavioural } \\
\text { problem }\end{array}$} & 36 & 45.5 & 39 & 60 & 30.5 & 42 & 39 & 42 \\
\hline & \multicolumn{2}{|c|}{ Epilepsy } & \multicolumn{2}{|c|}{ Seizure-type } & \multicolumn{2}{|c|}{$\begin{array}{l}\text { Duration } \\
\text { of epilepsy }\end{array}$} & \multicolumn{2}{|c|}{$\begin{array}{l}\text { Antiepileptic } \\
\text { drugs }\end{array}$} \\
\hline & $\begin{array}{c}\text { Non-active } \\
(n=37)\end{array}$ & $\begin{array}{c}\text { Active } \\
(n=99)\end{array}$ & $\begin{array}{c}\text { Single } \\
(n=91)\end{array}$ & $\begin{array}{l}\text { Multiple } \\
(n=52)\end{array}$ & $\begin{array}{l}<10 \text { yrs } \\
(n=13)\end{array}$ & $\begin{array}{c}>9 \mathrm{yrs} \\
(n=130)\end{array}$ & $\begin{array}{l}\text { Monotherapy } \\
\quad(n=73)\end{array}$ & $\begin{array}{l}\text { Polytherapy } \\
\qquad(n=63)\end{array}$ \\
\hline $\begin{array}{l}\text { Subjects with } \\
\text { behavioural } \\
\text { problems }\end{array}$ & 69 & 56 & 64 & 52 & 42 & 60 & 56 & 60 \\
\hline $\begin{array}{l}\text { Subjects } \\
\text { without } \\
\text { a behavioural } \\
\text { problem }\end{array}$ & 31 & 44 & 36 & 48 & 58 & 40 & 44 & 40 \\
\hline
\end{tabular}

Table 2

Percentage of subjects with or without a psychiatric illness in different subgroups of the cohort

\begin{tabular}{|c|c|c|c|c|c|c|c|c|}
\hline & \multicolumn{2}{|c|}{ Gender } & \multicolumn{2}{|c|}{ Age } & \multicolumn{2}{|c|}{$\begin{array}{l}\text { Degree of learning } \\
\text { disability }\end{array}$} & \multicolumn{2}{|c|}{ Accommodation } \\
\hline & $\begin{array}{c}\text { Male } \\
(n=82)\end{array}$ & $\begin{array}{l}\text { Female } \\
(n=61)\end{array}$ & $\begin{array}{l}18-64 \text { yrs } \\
(n=131)\end{array}$ & $\begin{array}{l}>64 \mathrm{yrs} \\
(n=12)\end{array}$ & $\begin{array}{c}\text { Mild } \\
(n=24)\end{array}$ & $\begin{array}{l}\text { Severe / Moderate } \\
\quad(n=103)\end{array}$ & $\begin{array}{l}\text { Hospital } \\
(n=78)\end{array}$ & $\begin{array}{l}\text { Community } \\
(n=65)\end{array}$ \\
\hline $\begin{array}{l}\text { Subjects with } \\
\text { a psychiatric } \\
\text { illness }\end{array}$ & 13 & 14 & 11 & 33 & 30 & 10 & 9 & 19 \\
\hline \multirow{3}{*}{$\begin{array}{l}\text { Subjects } \\
\text { without } \\
\text { a psychiatric } \\
\text { illness }\end{array}$} & 87 & 86 & 89 & $67^{a}$ & 70 & $90^{b}$ & 91 & 81 \\
\hline & \multicolumn{2}{|c|}{ Epilepsy } & \multicolumn{2}{|c|}{ Seizure-type } & \multicolumn{2}{|c|}{$\begin{array}{c}\text { Duration } \\
\text { of epilepsy }\end{array}$} & \multicolumn{2}{|c|}{$\begin{array}{c}\text { Antiepileptic } \\
\text { drugs }\end{array}$} \\
\hline & $\begin{array}{c}\text { Non-active } \\
(n=37)\end{array}$ & $\begin{array}{c}\text { Active } \\
(n=99)\end{array}$ & $\begin{array}{c}\text { Single } \\
(n=91)\end{array}$ & $\begin{array}{l}\text { Multiple } \\
(n=52)\end{array}$ & $\begin{array}{l}<10 \mathrm{yrs} \\
(n=13)\end{array}$ & $\begin{array}{c}>9 \mathrm{yrs} \\
(n=130)\end{array}$ & $\begin{array}{l}\text { Monotherapy } \\
\quad(n=73)\end{array}$ & $\begin{array}{l}\text { Polytherapy } \\
\quad(n=63)\end{array}$ \\
\hline $\begin{array}{l}\text { Subjects with } \\
\text { a psychiatric } \\
\text { illness }\end{array}$ & 19 & 12 & 11 & 17 & 31 & 11 & 14 & 11 \\
\hline $\begin{array}{l}\text { Subjects } \\
\text { without } \\
\text { a psychiatric } \\
\text { illness }\end{array}$ & 81 & 88 & 89 & 83 & 69 & 89 & 86 & 89 \\
\hline
\end{tabular}


Table 3

Percentage of subjects with behavioural problems or psychiatric illness in different subgroups according to EEG findings

\begin{tabular}{|c|c|c|c|c|c|c|}
\hline & \multicolumn{2}{|c|}{$\begin{array}{l}\text { Excessive } \\
\text { slow-wave }\end{array}$} & \multicolumn{2}{|c|}{$\begin{array}{l}\text { Epileptiform } \\
\text { changes }\end{array}$} & \multicolumn{2}{|c|}{$\begin{array}{l}\text { Epileptiform } \\
\text { changes }\end{array}$} \\
\hline & $\begin{array}{l}\text { Present } \\
(n=41)\end{array}$ & $\begin{array}{c}\text { Absent } \\
(n=23)\end{array}$ & $\begin{array}{l}\text { Present } \\
(n=26)\end{array}$ & $\begin{array}{c}\text { Absent } \\
(n=38)\end{array}$ & $\begin{array}{c}\text { Generalised } \\
\quad(n=12)\end{array}$ & $\begin{array}{c}\text { Focal } \\
(n=14)\end{array}$ \\
\hline $\begin{array}{l}\text { Subjects with } \\
\text { behavioral } \\
\text { problems }\end{array}$ & 59 & 64 & 62.5 & 51 & 56 & 57 \\
\hline $\begin{array}{l}\text { Subjects } \\
\text { without } \\
\text { behavioral } \\
\text { problems }\end{array}$ & 41 & 36 & 37.5 & 49 & 44 & 43 \\
\hline $\begin{array}{l}\text { Subjects with } \\
\text { a psychiatric } \\
\text { illness }\end{array}$ & 23 & 9 & 36 & $6^{a}$ & 29 & 29 \\
\hline $\begin{array}{l}\text { Subjects } \\
\text { without a } \\
\text { psychiatric } \\
\text { illness }\end{array}$ & 77 & 91 & 64 & 94 & 71 & 71 \\
\hline
\end{tabular}

\section{Discussion}

\subsection{Methodological problems}

Two main problems of this study are (a) retrospective nature of data collection based on information available from case-notes, although in many cases subjects were directly examined and the carers were interviewed, and (b) the lack of use of any validated behavioural rating scale. The diagnosis of psychiatric illness in a person with learning disability is problematic. It becomes more difficult when the diagnosis depends on information gathered from case notes. Another problem of this study is the lack of a suitably matched control group. However, data is available from previous studies on the rate of behavioural problems and psychiatric illness among learning disabled adults, with which data from the current study could be compared.

\subsection{Behavioural problems}

Smith and colleagues [17] found over $60 \%$ of 2117 learning disabled adults in a U.K. health district showed behavioural problems. Also, in a previous study we found $58 \%$ of learning disabled adults with epilepsy and $52 \%$ of a matched control group of nonepileptic learning disabled adults showed behavioural problems [8]. The rate of behavioural problem in the current study is similar to what was found in the above studies.

The type of behavioural problem in learning disabled patients was studied by Sigafoos and colleagues [16] and Harris [11], who found $11 \%$ of 2412 and $17.6 \%$ of 1362 learning disabled adults showed aggressive behaviour. A slightly higher proportion (19\%) of the cohort in the current study showed aggressive behaviour, although this difference was not statistically significant. Oliver and colleagues [15] found self injurious behaviour among $12 \%$ of learning disabled adults who lived in both hospital and community setting. A similar proportion (13\%) of the cohort in the current study showed self injurious behaviour. In a recent study, Collacott and colleagues [2] found self injurious behaviour in $17.4 \%$ of community based sample of learning disabled adults and no statistically significant difference in this behaviour was observed between patients with and without epilepsy.

In the current study epilepsy-related factors (i.e., seizure type, multiple versus single seizure, active versus non-active epilepsy, frequent versus non-frequent epilepsy, EEG types) did not significantly influence the rate of behavioural problems among the study cohort. On the basis of findings from the current study and other studies quoted above, there is no evidence to suggest that the rate of behavioural problems in general but aggression in particular is significantly higher among learning disabled adults with epilepsy compared with those without epilepsy. 


\subsection{Psychiatric illness}

The overall rate of psychiatric illness in the current study is comparable with that in the general population but is lower than what is expected in a learning disabled population $[1,12,13,14]$. In the past, prevalence studies of psychiatric illness in learning disabled adults $[1,12]$ included both functional psychiatric illness and behavioural problems within the diagnosis of a psychiatric illness, whereas in the current study the rate of psychiatric illness and behavioural problems are reported separately. The lack of a diagnosis of a bipolar affective disorder among the study cohort may highlight the problem of making this diagnosis in a person with learning disability. In the past when the rate of psychiatric illness was compared between learning disabled adults with and without epilepsy, bipolar affective disorder was diagnosed only among the matched control group of non- epileptic learning disabled adults [5]. As with behavioural problems, epilepsy-related factors did not significantly influence the rate of psychiatric illness among the study cohort. The overall rates and subtypes of psychiatric illness and behavioural disorders in adults with epilepsy and learning disability are comparable with those in adults with learning disability as a whole.

\section{Acknowledgements}

Authors wish to thank all subjects, carers and staff who took part in the study and also Mrs. J. Wheeler for patiently typing the manuscript.

\section{References}

[1] N. Bouras and C. Drummond, Behavioural and psychiatric disorders of people with mental handicaps living in the community, Journal of Intellectual Disability Research 36 (1992), 349-357.

[2] R.A. Collacott, S-A. Cooper, D. Branford and C. McGrowther, Epidermiology of self injurious behaviour in adults with learning disabilities, British Journal of Psychiatry 173 (1998), 428-432.
[3] Commission on Classification and Terminology of the International League Against Epilepsy, Proposal for revised clinical and electroencephalographic classification of epileptic seizures, Epilepsia 22 (1981), 489-501.

[4] S. Deb and D. Hunter, Psychopathology of people with mental handicap and epilepsy. 1: maladaptive behaviour, British Journal of Psychiatry 159 (1991), 822-826.

[5] S. Deb and D. Hunter, Psychopathology of people with mental handicap and epilepsy. 2: Psychiatric illness, British Journal of Psychiatry 159 (1991), 826-830.

[6] S. Deb and J. Joyce, Characteristics of epilepsy in a population based cohort of adults with learning disability, submitted to Irish Journal of Psychological Medicine.

[7] S. Deb, Epilepsy and Mental Retardation, Epilepsie Bulletin 25(4) (1997), 91-94.

[8] S. Deb, Mental disorder in adults with mental retardation and epilepsy, Comprehensive Psychiatry 38(3) (1997), 179-184.

[9] L.F. Eaton and F.J. Menolascino, Psychiatric disorders in the mentally retarded; types, problems and challenges, American Journal of Psychiatry 139 (1982), 1297-1303.

[10] R. Gostason, Psychiatric illness among the mentally retarded; a Swedish population study, Acta Psychiatrica Scandinavica (supplement 318) (1985), 1-117.

[11] P. Harris, The nature and extent of aggressive behaviour amongst people with learning difficulties (Mental handicap) in a single health district, Journal of Intellectual Disability Research 37 (1993), 221-242.

[12] J. Lund, The prevalence of psychiatric morbidity in mentally retarded adults, Acta Psychiatrica Scandinavica 72 (1985), 563-570.

[13] C.W. McGrother, A. Hauck, S. Bhaumik et al, Community care for adults with learning disability and their carers: needs and outcome from the Leicestershire register, Journal of Intellectual Disability Research 40 (1996), 183-190.

[14] H. Meltzer, B. Gill, M. Petticrew and K. Hinds, The prevalence of psychiatric morbidity among adults living in private households; OPCS survey of psychiatric morbidity in Great Britain: Report 1. Office of Population Censuses and Survey; HMSO, London, 1995.

[15] C. Oliver, G.H. Murphy and J.A. Corbett, Self injurious behaviour in people with mental handicap: a population study, Journal of Mental Deficiency Research 31 (1987), 147-162.

[16] J. Sigafoos, J. Elkins, M. Kerr et al, A survey of aggressive behaviour among a population of persons with intellectual disability in Queensland, Journal of Intellectual Disability Research 38 (1994), 369-381.

[17] S. Smith, D. Branford, R.A. Collacott et al, Prevalence and cluster typology of maladaptive behaviours in a geographically defined population of adults with learning disabilities, British Journal of Psychiatry 169 (1996), 219-227.

[18] International Classification of Diseases - 10th Revision (ICD10). World Health Organization, Geneva, 1993

[19] E.C. Wright, The presentation of mental illness in mentally retarded adults, British Journal of Psychiatry 141 (1982), 496-502. 


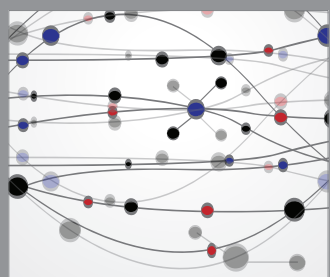

The Scientific World Journal
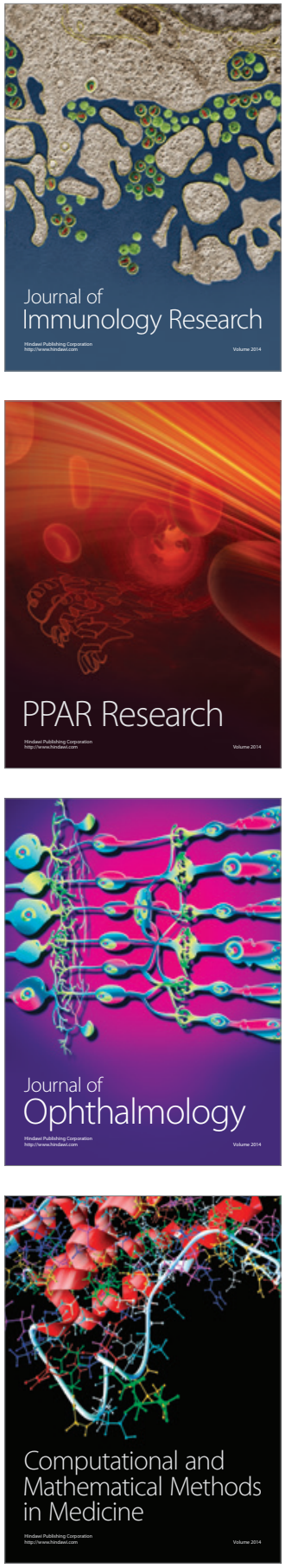

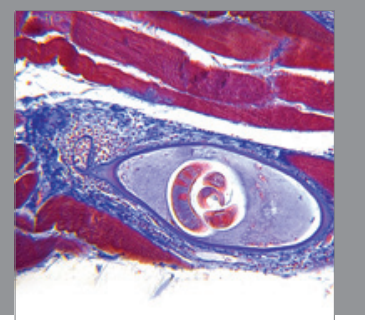

Gastroenterology

Research and Practice
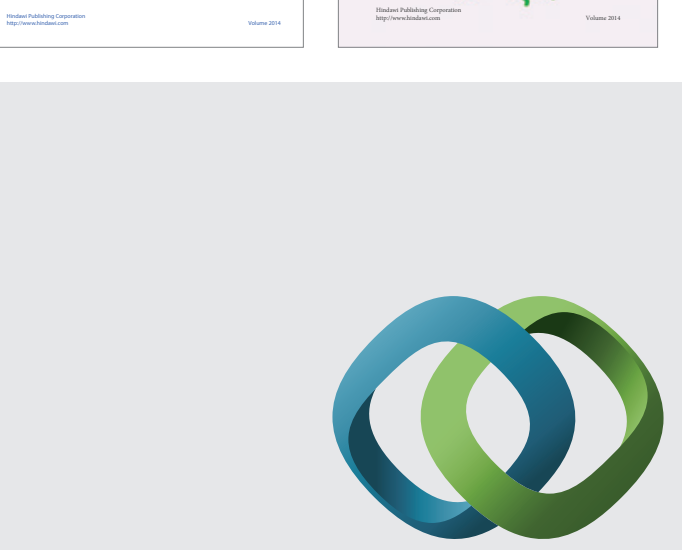

\section{Hindawi}

Submit your manuscripts at

http://www.hindawi.com
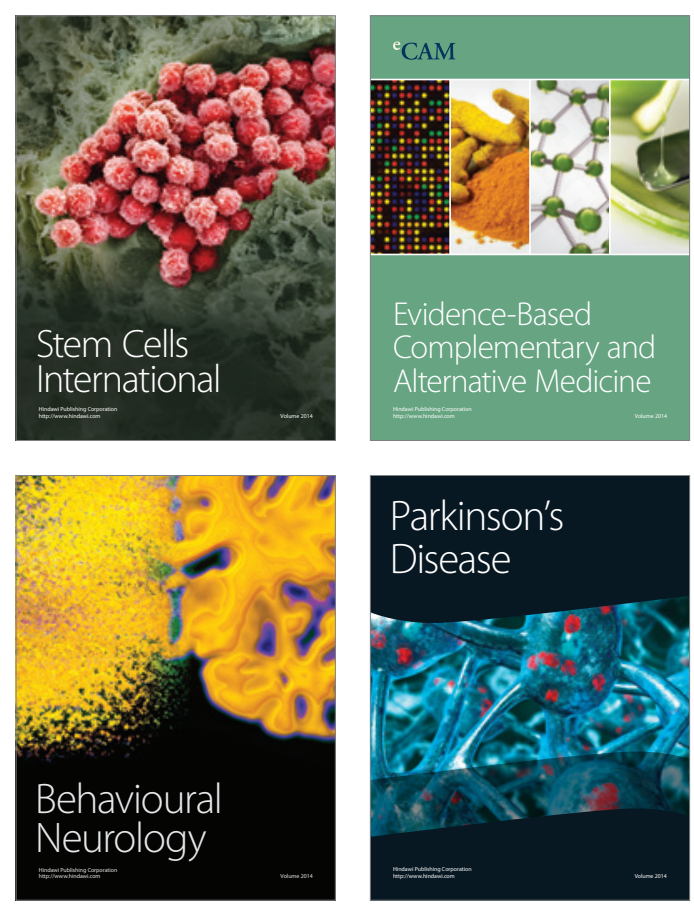

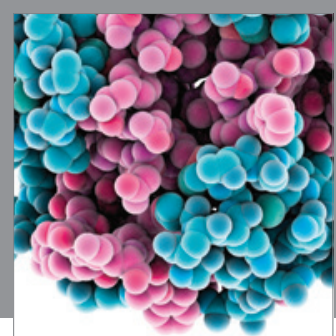

Journal of
Diabetes Research

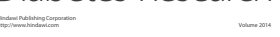

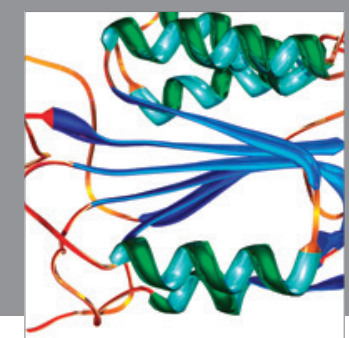

Disease Markers
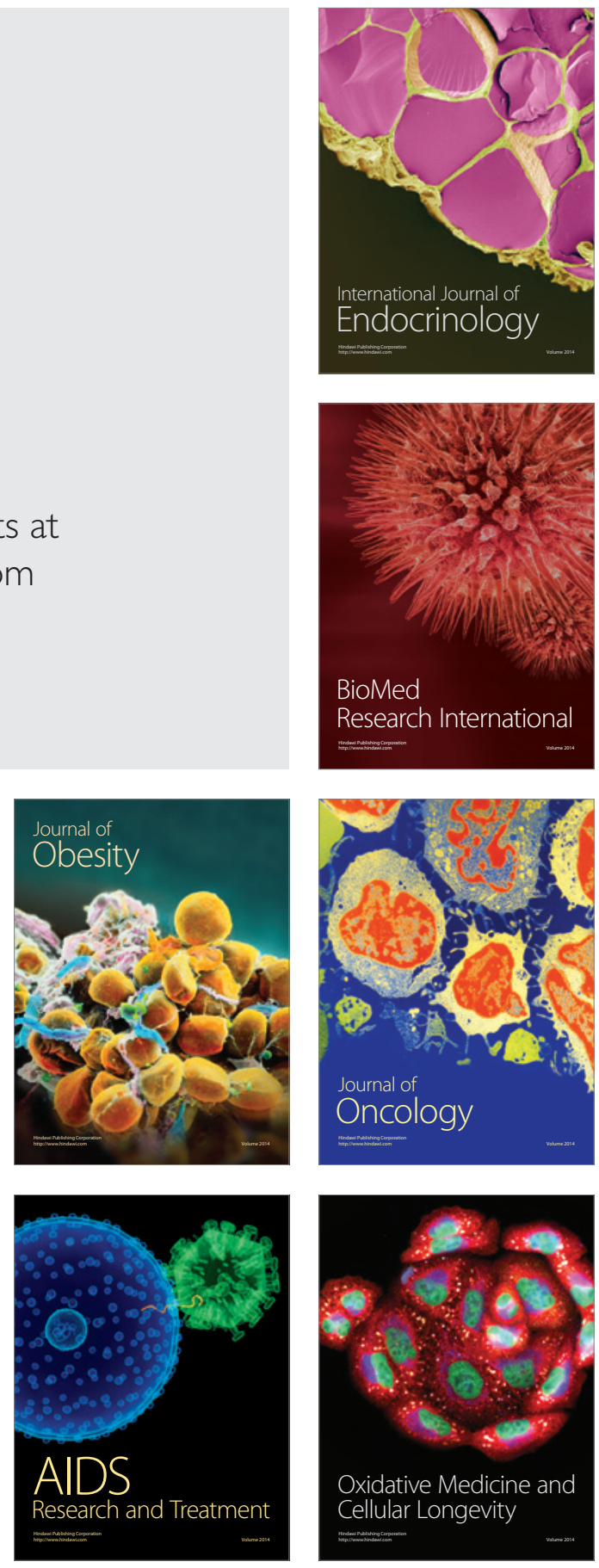